
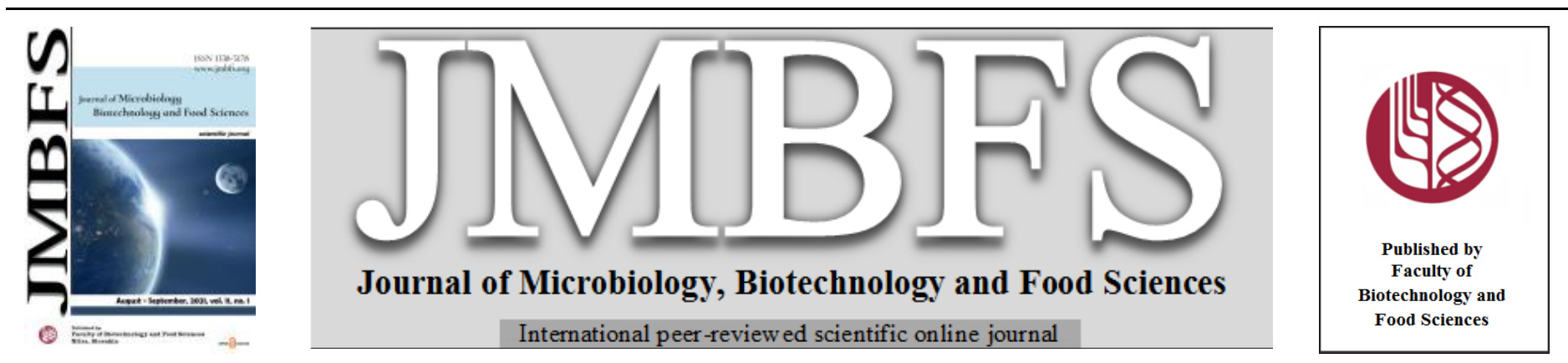

\title{
EXPLORATION OF EFFICIENCY OF NANO CALCIUM OXIDE (CaO) AS CATALYST FOR ENHANCEMENT OF BIODIESEL PRODUCTION
}

\author{
Muhammad Nor Fazli Abd Malek, Livitra Pushparaja, Noraini Mat Hussin, Nurul Hajar Embong, Prakash Bhuyar, Mohd Hasbi Ab. \\ Rahim, Gaanty Pragas Maniam*
}

Address(es): Dr. Gaanty Pragas Maniam,

Faculty of Industrial Sciences \& Technology, Universiti Malaysia Pahang, Lebuhraya Tun Razak, 26300 Gambang, Kuantan, Pahang, Malaysia.

*Corresponding author: gaanty@ump.edu.my

https://doi.org/10.15414/jmbfs.3935

\section{ARTICLE INFO}

Received 6.11.2020

Revised 6. 2. 2021

Accepted 10. 2. 2021

Published 1. 8. 2021

Regular article

OPEN $\partial_{\text {ACCESS }}$

\begin{abstract}
Present work proposes on the synthesis of nano calcium oxide derived from waste cockle shell (Anadara granosa) and applied as heterogenous catalyst in biodiesel production via transesterification reaction under reaction parameter 15:1 methanol to oil ratio, 5 wt.\% catalyst and 3 hour reation time and constant temperature at $65 \pm 2{ }^{\circ} \mathrm{C}$. The waste cockle shell was prepared in nano size via ball mill technique which was run for 36 hours at $350 \mathrm{rpm}$ speed and then calcined at $900{ }^{\circ} \mathrm{C}$ for 2 hours to decompose calcium carbonate, $\mathrm{CaCO}_{3}$ into nano calcium oxide, $\mathrm{n}-\mathrm{CaO}$. The catalyst was characterized by particle size analyzer, Transmission Electron Microscopy, Field Emission Scanning Electron Microscope, Surface Area Analyser, X-Ray Diffractometer, Fourier transform infrared, Hammet indicator and benzoic acid titration. Particle size of $\mathrm{n}-\mathrm{CaO}$ catalyst was found within the range of $29 \mathrm{~nm}$ to $67.5 \mathrm{~nm}$. Specific surface area of synthesised $\mathrm{n}-\mathrm{CaO}$ is $8.41 \mathrm{~m}^{2} / \mathrm{g}$ with basicity strength of $0.055 \mathrm{mmol} / \mathrm{g}$. Methyl ester conversion of palm oil with $\mathrm{n}-\mathrm{CaO}$ as a catalyst was 88.87 wt.\%.
\end{abstract}

Keywords: cockle shell, nano $\mathrm{CaO}$ as heterogeneous catalyst, particle size, specific surface area, basicity strength, methyl ester yield

\section{INTRODUCTION}

Massive consumption of fossil fuel for numerous purposes cause the deficiency of natural resources available nowadays. At the same time fully relying on renewable energy sources such as solar, wind energy and biomass as an alternative energy source makes life of people even more devastating as this type of energy source not always available at any time anywhere and expensive. This cause biodiesel becoming better and cheaper alternative than any other sources (Banković-Ilić et al., 2017; Bhuyar et al., 2020; Saengsawang et al., 2020).

Generally, biodiesel is biodegradable, nontoxic, and has lower carbon dioxide and sulfur emissions when utilised in internal combustion engines. Biodiesel can be produced via several processing method. It can be produced via supercritical process, catalyst-free mehod at high temperature and pressure (Bunyakiat et al. 2006), ultrasonic reactor method (Malek et al., 2020) and enzyme-catalysed method (Du et al., 2004). Common way of producing biodiesel is through transesterification process of oils or fats with methanol (Ahmad et al., 2020). Biodiesel feedstock can be derived from various sources such as plant oils (Ge, Yoon, and Choi 2017; Ishola et al., 2020), animal (Toldrá-Reig, Mora, and Toldrá 2020), microalgae (Khammee et al., 2020) and microbial (Bhuyar et al., 2020; Boock et al., 2019). Transesterification reaction of biodiesel can be accelerated with the aid of inorganic (heterogeneous or homogeneous) or organic catalysts (enzymes). Inorganic heterogeneous catalysts offer abundant benefits relative to either inorganic homogenous or organic catalyst including ease of separation, recovery of catalyst, reusability of catalyst, cheap and minimized corrosion (Mazaheri et al., 2018; Bhuyar et al., 2019).

Among the heterogeneous catalyst that was used in transesterification reaction, calcium oxide, $\mathrm{CaO}$ proven to be highly effective catalyst in biodiesel production by many literature studies. $\mathrm{CaO}$ is inexpensive, easily available, noncorrosive, environmentally friendly, easy to handle material with low solubility and high basicity which can be reused (Borah $\boldsymbol{e t}$ al., 2019). These benefits triggered interest of many researchers for further investigations of $\mathrm{CaO}$ for the purpose of improvement of its properties. There are abundant sources of $\mathrm{CaO}$ around the world, but the cockle shell (Anadara granosa) is known to be rich in $\mathrm{CaO}$. The generation of waste cockle shells which are easily available make it feasible for the shell to be used as a catalyst in the biodiesel industry which lead to production of biodiesel in an inexpensive way as the catalyst used is derived from waste shell as well.
However, according to (Banković-Ilić $\boldsymbol{e t}$ al., 2017), the role of nanoparticles in catalytic processes affect conversion rate of methyl ester due to their catalytic properties, which are very high surface reactivity, large pore size and large surface area compared to macroscopic catalysts. It makes the nano size particle to be more attractive as catalysts for higher conversion rate of methyl ester in biodiesel production.

Hence, the main purpose of this study is to prepare nano calcium oxide, $\mathrm{nCaO}$ catalyst from cockle shells (Anadara granosa) and evaluate the performance of the synthesized $n-\mathrm{CaO}$ compared to commercial calcium oxide $\mathrm{c}-\mathrm{CaO}$ as a catalyst in the transesterification of palm oil into biodiesel. The properties of both catalysts were studied via characterization by particle size analyzer, Transmission Electron Microscopy, Field Emission Scanning Electron Microscope, Surface Area Analyser, X-Ray Diffractometer, Fourier transform infrared, Hammet indicator and Benzoic acid titration. The reaction parameters which are methanol to oil ratio, reaction time, and catalyst amount are optimized to $15: 1,3$ hours, and $5 \%$ respectively. Finally, the comparison of methyl ester conversion at each 30 minutes interval for both $\mathrm{n}-\mathrm{CaO}$ and $\mathrm{c}-\mathrm{CaO}$ catalyzed reaction was determined through analysis of thin layer chromatography and gas chromatography-flame ionization detector.

\section{MATERIAL AND METHODS}

\section{Materials}

Refined bleached deodorized palm oil (RBDPO) was purchased from local groceries. Waste cockle shells were collected from local restaurants. Internal standard (methyl heptadecanoate) and calcium oxide were obtained from SigmaAldrich. Potassium hydroxide, methanol, acetone, and n-hexane were obtained from Merck. Chloroform was provided by Surechem product Ltd. (Soffolk,England) and phenolphthalein $(\mathrm{H}+=8.2)$, 2,4-dinitroanilline $(\mathrm{H}+=15.0)$, 4-nitroanilline $(\mathrm{H}+=18.4)$ were purchased from Sigma (Deisenhofen,Germany). Both anhydrous sodium sulphate and petroleum ether $\left(60{ }^{\circ} \mathrm{C}-80{ }^{\circ} \mathrm{C}\right)$ were obtained from BDH Chemical Ltd.(Poole,England). All the chemicals mentioned above were analytical reagent grade. Thin Layer Chromatography (TLC) aluminum sheets were purchased from Merck (Darmstadt, Germany). 


\section{Preparation of catalyst}

The waste cockle shells were washed thoroughly with warm water and then dried under daylight for 48 hours before crushed in a pestle and mortar. Then, the crushed shells were grinded using a dry mill grinder to obtain gross powder and sieved using $100 \mu \mathrm{m}$ sieve tray and micron sized powder obtained. After that, ball milling process for 36 hours with $350 \mathrm{rpm}$ speed was conducted using Planetary Ball Mill (Retsch, PM100) to get further finest powder in nano size. After been ball milled, half amount of the ball milled powder was calcined in furnace at $900{ }^{\circ} \mathrm{C}$ for 2 hours. The calcined $\mathrm{CaO}$ powder (labeled as $\mathrm{n}-\mathrm{CaO}$ ) was stored in an air-tight glass container and then placed inside a desiccator to avoid any moisture content. The $\mathrm{c}-\mathrm{CaO}$ powder was also calcined at $900{ }^{\circ} \mathrm{C}$ for 2 hours to be used as reference to compare its efficiency with the synthesized n-CaO in biodiesel yield.

\section{Catalyst Characterization}

The surface morphology of the synthesized uncalcined and calcined n-CaO catalyst were studied through scanning electron microscopy with electron dispersive $\mathrm{x}$-ray (SEMEDEX) that was obtained using Field Emission SEM (FESEM). Malvern Zeta sizer model Nano-S90 particle size analyzer measured average particle size distribution of catalyst. photomicrographs were obtained using FEI/Technai G2 20 TWIN model Transmission Electron Microscope. The surface area of the catalyst was determined using Micromeritics ASAP 2020 by using Brunauer, Emmet and Teller (BET) analysis from the corresponding nitrogen adsorption-desorption isotherms at liquid nitrogen temperature (-196 ${ }^{\circ} \mathrm{C}$ ). The $\mathrm{x}$-ray diffraction analysis (XRD) was used to study the crystallography of calcium carbonate, $\mathrm{CaCO}_{3}$ and $\mathrm{CaO}$ presence in the synthesized uncalcined and calcined nano catalysts using an X-ray Diffractometer (Bruker, model D8 Advance). FTIR Perkin Elmer System 2000 instrument used to determine the surface functional group of the solid catalyst compound in the range of 400 to $4000 \mathrm{~cm}^{-1}$. The Hammett indicators such as phenolphthalein $\left(\mathrm{H}_{-}=9.3\right), 2,4$ dinitroaniline $\left(\mathrm{H}_{-}=15.0\right)$ and 4-nitroniline $\left(\mathrm{H}_{-}=18.4\right)$ were used to determine the catalyst basicity strength. Solid catalyst basicity was analyzed by benzoic acid titration method (Bampidis and Robinson 2006) where the solid catalyst was suspended in benzene and was titrated with $0.01 \mathrm{~N}$ benzoic acid. The endpoint of titration was determined when all the green color disappeared.

\section{Transesterification}

Biodiesel was produced from palm oil through base-catalyzed transesterification process with presence of methanol and potassium hydroxide as catalyst. The reaction was done at condition of 15:1 methanol to oil ratio, $5 \%$ catalyst and 3 hours reaction time at constant temperature of $68 \pm 2{ }^{\circ} \mathrm{C}$ was carried out. The contents were refluxed under magnetic stirring. Tap water was allowed to flow inside the condenser to prevent methanol from evaporating which might ruin the reaction. At each $30 \mathrm{~min}$ interval, small amount of sample from the product mixture in the flask reactor were taken. The samples were centrifuged at 5000 $\mathrm{rpm}$ for 20 minutes to reach complete phase separation. After that, fatty acid methyl ester (the top layer) was analyzed to determine the percentage content of methyl ester.

\section{Analysis and characterization of methyl ester}

In thin layer chromatography (TLC) technique, sample and standard (methyl heptadecanoate) were dotted on the plate and left inside the flask containing the mixture of petroleum ether and chloroform (3:2 volume ratio). Once the solvent has reached the upper line drawn at the top as indicator, TLC plate was taken out and shaken with small amount of solid iodine to enable separation to be seen very well. Besides, standard and sample was analyzed through gas chromatography (Agilent 7890A-GC) using flame ionization detector (FID) with a polar capillary column (HP-INNOWax $30 \mathrm{~m} \times 0.25 \mathrm{~mm}$, i.d $\times 0.25 \mu \mathrm{m}$ ) was used to determine conversion of methyl ester. As for characterization of methyl ester was carried out in terms of acid value (ASTM D664).

\section{RESULTS AND DISCUSSION}

\section{Catalyst characterization}

\section{Field emission scanning electron microscope (FESEM)}

FESEM analysis proved that calcination process at $900{ }^{\circ} \mathrm{C}$ for 2 hours on $n-\mathrm{CaO}$ catalyst prepared from cockle shell changed the morphology of the $\mathrm{CaO}$ from irregular shapes to a smooth cluster of well- developed cubic crystal. Besides, more pores with smooth surface was shown by calcined $\mathrm{CaO}$ nano catalyst as shown in figure 1 (a) compared to uncalcined $\mathrm{CaO}$ nano catalyst where a rough surface with no pores observed as shown in figure 1(b).
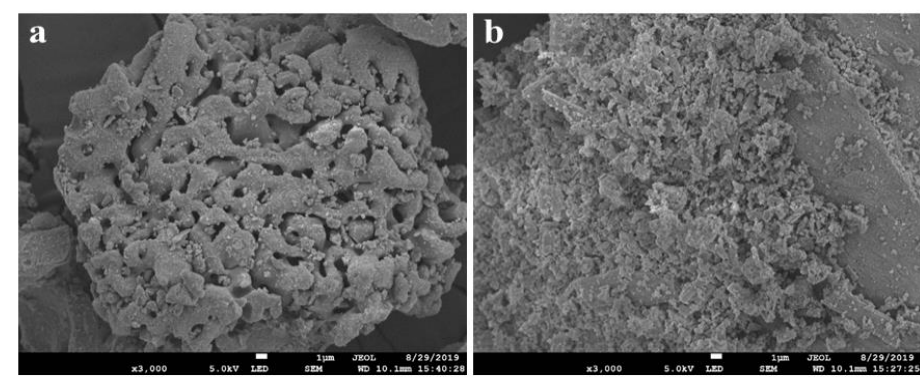

Figure 1 FESEM micrographs of (a) calcined nano $\mathrm{CaO}$ and (b) uncalcined nano $\mathrm{CaO}$

\section{Particle size analysis}

Particle size distribution of the uncalcined $\mathrm{CaO}$ were mostly in the range between 1000 to $10000 \mathrm{~nm}$ but after calcined at $900{ }^{\circ} \mathrm{C}$ for 2 hours, its size reduced to below $1000 \mathrm{~nm}$. This proved that calcination process leads to reduction of particle size of the $\mathrm{CaO}$ catalyst. Whereas, the synthesized $\mathrm{CaO}$ catalyst before ball milled was $969.3 \mathrm{~nm}$ in size but after ball milled for 36 hours at $350 \mathrm{rpm}$ speed the particle size obtained was $104 \mathrm{~nm}$ and the frequency distribution curve for this was shown in figure 2 (a). This proved that ball milling process is an efficient way that able to reduce the micron size particles to nano scale particles (Wong et al., 2014).

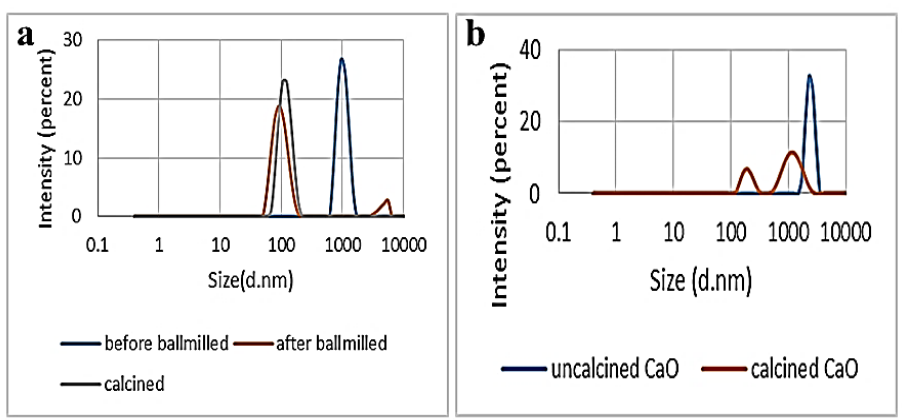

Figure 2 Zone Graph of size distribution by intensity of (a) synthesised n-CaO and (b) c-CaO catalyst

\section{Transmission electron microscopy (TEM)}

Based on the TEM result, the size of the synthesized $\mathrm{CaO}$ is in the range from 29 $\mathrm{nm}$ to $67.5 \mathrm{~nm}$ and the average particle size of the synthesized nano calcined $\mathrm{CaO}$ is approximately $43.16 \mathrm{~nm}$. Hence, it is proven that through ball milling process for 36 hours at $350 \mathrm{rpm}$ speed the shell derived $\mathrm{CaO}$ catalyst can be made into nano size catalyst powder.

\section{Surface area analysis (BET)}

Surface area of n-CaO and c-CaO was determined by Brunauer-Emmett-Teller analysis and gave a BET value of $8.41 \mathrm{~m} 2 / \mathrm{g}$ and $3.0 \mathrm{~m} 2 / \mathrm{g}$, respectively. $\mathrm{n}-\mathrm{CaO}$ and $\mathrm{c}-\mathrm{CaO}$. The smaller particle size of nano $\mathrm{CaO}$ catalyst cause its surface area to be larger. According to the International Union of Pure and Applied Chemistry classification, calcined commercial $\mathrm{CaO}$ figure 3(a) catalyst exhibit type $\mathrm{V}$ isotherm which explained non-porous form of catalyst. Whereas, $\mathrm{CaO}$ catalys exhibit the type-IV isotherm based on figure 3(b) with type H4 hysteresis loop, which means that the synthesized catalysts having mesoporous structure.
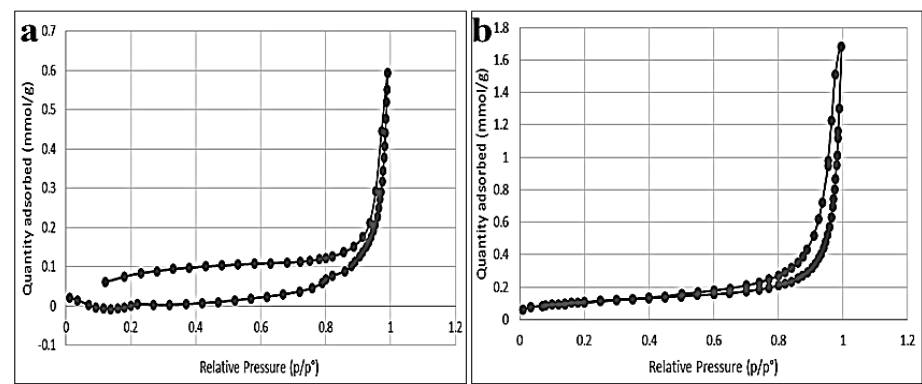

Figure $3 \mathrm{~N}_{2}$ adsorption-desorption isotherm of (a) calcined commercial $\mathrm{CaO}$ and (b) calcined nano $\mathrm{CaO}$

\section{$X$-ray diffraction $(X R D)$ analysis}

Figure 4(a) shows the XRD pattern of the synthesized nano $\mathrm{CaCO}_{3}$ powder before calcination treatment at $900^{\circ} \mathrm{C}$ for 2 hours the peaks at $2 \theta 27.42 \theta, 33.29 \theta$ 
$38.69 \theta, 46.03 \theta 48.57 \theta$, and $52.56 \theta$ with higher intensity indicated the presence of carbonate $\left(\mathrm{CO}_{3}{ }^{2}\right)$ in that sample. The main peaks of $\mathrm{CaCO}_{3}$ observed on the uncalcined nano $\mathrm{CaCO}_{3}$ catalyst were very similar with data from Join Committee on Powder Diffraction Standard (JCPDS) file. Presence of $\mathrm{CaO}$ peaks at $2 \theta 32.25 \theta, 37.3 \theta, 53.96 \theta, 64.24 \theta$ and $67.46 \theta$ were observed for the synthesized calcined nano $\mathrm{CaO}$ catalyst as shown in figure 4 (b).
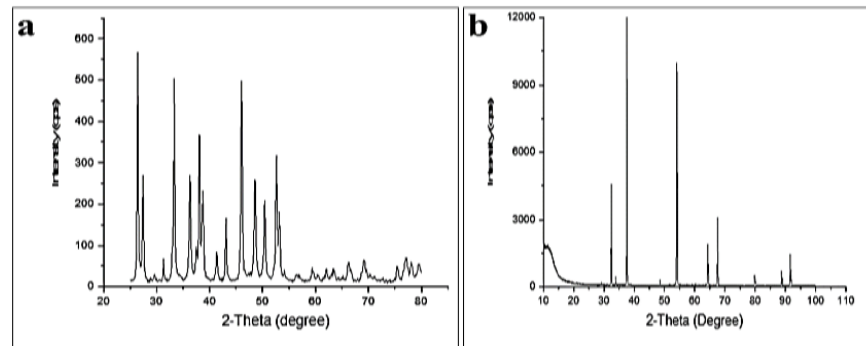

Figure $4 \mathrm{XRD}$ pattern of the synthesized $\mathrm{n}-\mathrm{CaO}$ (a) before and (b) after calcined.

\section{Fourier Transform Infrared Spectroscopy (FTIR)}

As shown in figure 5(b), the appearance of a small peak at $2922.45 \mathrm{~cm}-1$ absorption band depicted that there is still some carbonate, $\mathrm{CO}_{3} 2$ - compound at very low intensity available in the commercial calcined $\mathrm{CaO}$ catalyst. This might be due to the incomplete decomposition of the $\mathrm{CaCO}_{3}$ into $\mathrm{CaO}$. Whereas, the disappearance of moderate to weak signals and the shifting of absorption bands corresponding to $\mathrm{CO}_{3} 2-$ after calcination of the synthesized nano $\mathrm{CaO}$ as shown in figure 5 (a) verified the decomposition of $\mathrm{CaCO} 3$ to $\mathrm{CaO}$. IR absorption bands in the uncalcined and calcined cockle shell derived $\mathrm{CaO}$ catalyst spectra completely matched with FTIR spectrum of the reported literature (Laskar et al., 2018)

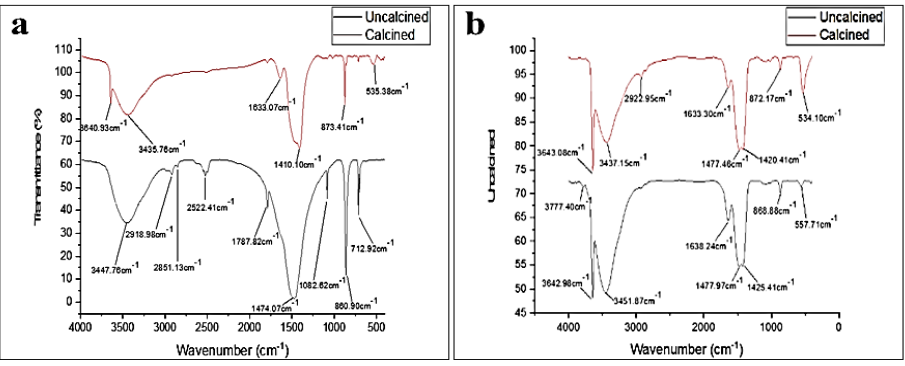

Figure 5 FTIR spectrum of the (a) synthesized nano $\mathrm{CaO}$ catalyst before and after calcined and (b) commercial $\mathrm{CaO}$ catalyst before and after calcined.

\section{Hammett Indicator}

The color of 2,4-dinitroaniline and 4-nitroaniline remain unchanged whereas color of phenolphthalein indicator changes to pink after 2 hours for both calcined commercial and $\mathrm{n}-\mathrm{CaO}$ catalyst indicating $\mathrm{H}$ value for both the catalyst falls within the range of 8.2 to 15

\section{Benzoic acid titration method}

The basicity value of the synthesized nano calcined $\mathrm{CaO}$ was $0.055 \mathrm{mmol} / \mathrm{g}$ which is higher than commercial calcined $\mathrm{CaO}$ which is $0.025 \mathrm{mmol} / \mathrm{g}$. The result obtained was supported by research findings (Syazwani et al., 2017), where natural derived waste shell contains higher amount of total basicity than commercial $\mathrm{CaO}$ catalyst which responsible for its higher catalytic activity.

\section{Analysis of methyl ester}

Based on Thin Layer Chromatography (TLC) result, the conversion rate of oil to methyl ester for calcined $\mathrm{n}-\mathrm{CaO}$ catalyzed transesterification was found to be faster at each 30 minutes interval compared to calcined $\mathrm{c}-\mathrm{CaO}$ catalyzed transesterification reaction. According to GC-FID result as shown in figure 3.6, it was shown that the overall rate of conversion of palm oil to methyl ester when using synthesized calcined $\mathrm{n}-\mathrm{CaO}$ catalyst was much greater compared to that of calcined $\mathrm{c}-\mathrm{CaO}$ catalyst. For the synthesized $\mathrm{n}-\mathrm{CaO}$ catalyst, the nano size of the catalyst particle possess a large BET surface area which increase the availability of the basic sites on the catalyst surface for reaction compared to the $\mathrm{c}-\mathrm{CaO}$ catalyst (Maniam et al., 2015). This accelerates the rate of transesterification contributing to higher conversion of oil to methyl ester (Bharti, Singh, and Dey 2019).

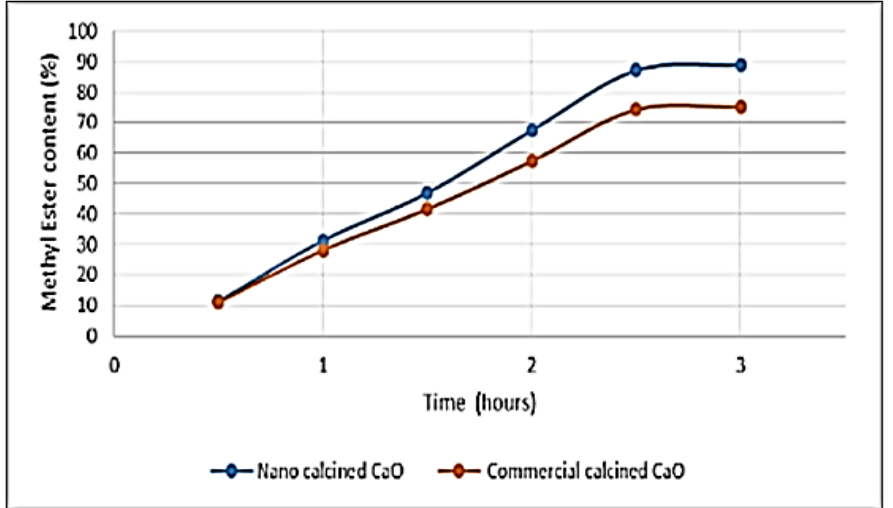

Figure 6 Graph of methyl ester yield (\%) against time for both commercial and nano calcined $\mathrm{CaO}$ catalyst.

\section{Characterization of methyl ester}

The acid value of methyl ester obtained using commercial $\mathrm{CaO}$ catalyst were much higher than that of using the synthesized nano $\mathrm{CaO}$ catalyst which were confirmed with the ASTM standard.

\section{CONCLUSION}

$\mathrm{CaO}$ nanostructure derived from Anadara granosa cockle shell was prepared by calcination process at $900{ }^{\circ} \mathrm{C}$ for 2 hours. $\mathrm{n}-\mathrm{CaO}$ exhibit better catalyst performance compared to $\mathrm{c}-\mathrm{CaO}$ with higher methyl ester conversion of $(88.87 \%)$. According to the obtained results, nanostructure of $\mathrm{CaO}$ catalyst provides a better characteristic of catalyst. Higher BET surface area $(8.41 \mathrm{~m} 2 / \mathrm{g})$, smaller particle size $(\sim 100 \mathrm{~nm})$ and higher basicity $(0.055 \mathrm{mmol} / \mathrm{g})$ contribute to the higher catalytic activity in transesterification reaction compared to $\mathrm{c}-\mathrm{CaO}$ Smaller particles increase the number of available active sites for the transesterification reaction to occur effectively and with higher rate, that are evident from the higher methyl esters conversion as well as higher basicity.

Acknowledgments: The authors gratefully acknowledged Universiti Malaysia Pahang (UMP) for the financial assistance through the Fundamental Research Grant Scheme (FRGS) FRGS/1/2019/STG01/UMP/02/2. Authors are thankful to UMP and Central Laboratory for providing research facilities.

\section{REFERENCES}

Ahmad, M.S., Cheng, C.K., Bhuyar, P., Atabani, A.E., Pugazhendhi, A., Chi, N.T.L., Witoon, T., Lim, J.W., Juan, J.C. (2021). Effect of reaction conditions on the lifetime of SAPO-34 catalysts in methanol to olefins process-A review. Fuel, 283, p.118851. https://doi.org/10.1016/j.fuel.2020.118851

Bampidis, V. A., \& Robinson, P. H. (2006). Citrus by-products as ruminant feeds: A review. Animal Feed Science and Technology, 128(3-4), 175-217. https://doi.org/10.1016/j.anifeedsci.2005.12.002

Banković-Ilić, I. B., Miladinović, M. R., Stamenković, O. S., \& Veljković, V. B. (2017). Application of nano $\mathrm{CaO}$-based catalysts in biodiesel synthesis Renewable and Sustainable Energy Reviews, 72, 746-760 https://doi.org/10.1016/j.rser.2017.01.076

Bharti, P., Singh, B., \& Dey, R. K. (2019). Process optimization of biodiesel production catalyzed by $\mathrm{CaO}$ nanocatalyst using response surface methodology. Journal of Nanostructure in Chemistry, 9(4), 269-280. https://doi.org/10.1007/s40097-019-00317-w

Bhuyar, P., Rahim, M. H. A., Sundararaju, S., Ramaraj, R., Maniam, G. P., \& Govindan, N. (2020). Synthesis of silver nanoparticles using marine macroalgae Padina sp. and its antibacterial activity towards pathogenic bacteria. Beni-Sue Univ J Basic Appl Sci, 9(1), 1-15. https://doi.org/10.1186/s43088-019-0031-y

Bhuyar, P., Sundararaju, S., Math, K. R., Maniam, G. P., Govindan, N. (2020). Production of bioethanol from starchy tuber (Amorphophallus commutatus) and antimicrobial activity study of its extracts. Afr. J. of Bio. Sci., 2(2), 70-76. https://doi.org/10.33472/AFJBS.2.2.2020.70-76

Bhuyar, P., Sundararaju, S., Rahim, M. H. A., Ramaraj, R., Maniam, G. P., \& Govindan, N. (2019). Microalgae cultivation using palm oil mill effluent as growth medium for lipid production with the effect of $\mathrm{CO} 2$ supply and light intensity. Biomass Conv. Bioref.1-9. https://doi.org/10.1007/s13399-019-00548-5 Bhuyar, P., Yusoff, M. M., Rahim, M. H. A., Sundararaju, S., Maniam, G. P., Govindan, N. (2020). Effect of plant hormones on the production of biomass and lipid extraction for biodiesel production from microalgae chlorella sp." The J. of Micro. Biotech. and Food Sci. 9, no. 4 (2020): 671 . https://doi.org/10.15414/jmbfs.2020.9.4.671-674

Bhuyar, P., Rahim, M. H. A., Yusoff, M. M., Maniam, G. P., Govindan, N. (2019). A selective microalgae strain for biodiesel production in relation to higher lipid profile. Maejo Int J Energy Environ Commun, 1(1), 8-14. 
Boock, J.T., Freedman, A.J., Tompsett, G.A., Muse, S.K., Allen, A.J., Jackson, L.A., Castro-Dominguez, B., Timko, M.T., Prather, K.L. and Thompson, J.R., 2019. Engineered microbial biofuel production and recovery under supercritical carbon dioxide. Nature communications, 10(1), pp.1-12. 587 https://doi.org/10.1038/s41467-019-08486

Borah, M. J., Das, A., Das, V., Bhuyan, N., \& Deka, D. (2019). Transesterification of waste cooking oil for biodiesel production catalyzed by $\mathrm{Zn}$ substituted waste eggshell derived $\mathrm{CaO}$ nanocatalyst. Fuel, 242, 345-354. https://doi.org/10.1016/j.fuel.2019.01.060

Bunyakiat, K., Makmee, S., Sawangkeaw, R., \& Ngamprasertsith, S. (2006). Continuous production of biodiesel via transesterification from vegetable oils in supercritical methanol. Energy \& Fuels, 20(2), 812-817. https://doi.org/10.1021/ef050329b

Du, W., Xu, Y., Liu, D., \& Zeng, J. (2004). Comparative study on lipasecatalyzed transformation of soybean oil for biodiesel production with different acyl acceptors. Journal of Molecular Catalysis B: Enzymatic, 30(3-4), 125-129. https://doi.org/10.1016/j.molcatb.2004.04.004

Ge, J. C., Yoon, S. K., \& Choi, N. J. (2017). Using canola oil biodiesel as an alternative fuel in diesel engines: A review. Applied Sciences, 7(9), 881 https://doi.org/10.3390/app7090881

Ishola, F., Adelekan, D., Mamudu, A., Abodunrin, T., Aworinde, A., Olatunji, O., \& Akinlabi, S. (2020). Biodiesel production from palm olein: A sustainable bioresource for Nigeria. Heliyon, 6(4), e03725 https://doi.org/10.1016/j.heliyon.2020.e03725

Khammee, P., Ramaraj, R., Whangchai, N., Bhuyar, P., Unpaprom, Y. (2020) The immobilization of yeast for fermentation of macroalgae Rhizoclonium sp. for efficient conversion into bioethanol. Biomass Conv. Bioref.53:2. https://doi.org/10.1007/s13399-020-00786-y

Laskar, I. B., Rajkumari, K., Gupta, R., Chatterjee, S., Paul, B., \& Rokhum, L. (2018). Waste snail shell derived heterogeneous catalyst for biodiesel production by the transesterification of soybean oil. RSC advances, 8(36), 20131-20142. https://doi.org/10.1039/C8RA02397B

Malek, M.N.F.A., Hussin, N.M., Embong, N.H., Bhuyar, P., Rahim, M. H. A. Govindan, N., Maniam, G. P. (2020). Ultrasonication: a process intensification tool for methyl ester synthesis: a mini review. Biomass Conv. Bioref. https://doi.org/10.1007/s13399-020-01100-6

Maniam, G. P., Hindryawati, N., Nurfitri, I., Manaf, I. S. A., Ramachandran, N., \& Rahim, M. H. A. (2015). Utilization of waste fat from catfish (Pangasius) in methyl esters preparation using $\mathrm{CaO}$ derived from waste marine barnacle and bivalve clam as solid catalysts. Journal of the Taiwan Institute of Chemical Engineers, 49, 58-66. https://doi.org/10.1016/j.jtice.2014.11.010

Mazaheri, H., Ong, H. C., Masjuki, H. H., Amini, Z., Harrison, M. D., Wang, C. T., ... \& Alwi, A. (2018). Rice bran oil-based biodiesel production using calcium oxide catalyst derived from Chicoreus brunneus shell. Energy, 144, 10-19. https://doi.org/10.1016/i.energy.2017.11.073

Saengsawang, B., Bhuyar, P., Manmai, N., Ponnusamy, V. K., Ramaraj, R., Unpaprom, Y. (2020). The optimization of oil extraction from macroalgae, Rhizoclonium sp. by chemical methods for efficient conversion into biodiesel. Fuel, 274, 117841. https://doi.org/10.1016/j.fuel.2020.117841

Syazwani, O. N., Teo, S. H., Islam, A., \& Taufiq-Yap, Y. H. (2017) Transesterification activity and characterization of natural $\mathrm{CaO}$ derived from waste venus clam (Tapes belcheri S.) material for enhancement of biodiese production. Process Safety and Environmental Protection, 105, 303-315. https://doi.org/10.1016/j.psep.2016.11.011

Toldrá-Reig, F., Mora, L., \& Toldrá, F. (2020). Trends in Biodiesel Production from Animal Fat Waste. Applied Sciences, 10(10), 3644 https://doi.org/10.3390/app10103644

Wong, Y. C., Y. P. Tan, Y. H. Taufiq-Yap, and I. Ramli. 2014. "Effect of Calcination Temperatures of $\mathrm{CaO} / \mathrm{Nb} 2 \mathrm{O} 5$ Mixed Oxides Catalysts on Biodiesel Production." Sains Malaysiana 43(5):783-90. 